\title{
Which is More Important and Insidious in Dialysis Patients? Occult Hepatitis B or Occult Hepatitis C?
}

\author{
Diyaliz Hastalarında Hangisi Daha Önemli ve Sinsidir? Okült Hepatit B veya Okült \\ Hepatit C mi?
}

• Özlem Zanapalığlu Gazel, • Alper Şener

Onsekiz Mart University Faculty of Medicine, Department of Infectious Disease, Çanakkale, Turkey

\begin{abstract}
Objectives: The aim of this study was to investigate the presence of occult hepatitis B infection (OBI) and Occult hepatitis $\mathrm{C}$ infection $(\mathrm{OCl})$ in hemodialysis patients and to determine whether there is an activation in the follow-up or not.

Materials and Methods: Demographic data, causes of renal failure, access to hemodialysis, duration of hemodialysis, alanine aminotransferase (ALT) levels, hepatitis indicators of $100 \mathrm{HD}$ patients with normal ALT levels were recorded in this study. Serum anti-hepatitis B core antibody (anti-HBc) immunoglobulin G (lgG) was tested with ELISA (Architecht, Abbott). Serum hepatitis B virus (HBV)-DNA, HCV-RNA [in peripheral blood mononuclear cells (PBMNC)] were studied with "real-time" polymerase chain reaction method.

Results: Anti-HBc IgG positivity was detected in $27 \%$ of patients, but with no isolated anti-HBc IgG positivity. In $4 \%$ of the patients, HBV-DNA positivity and $\mathrm{OBI}$ infection were detected. None of the patients showed HCV-RNA positivity in serum and in PBMNC, therefore $\mathrm{OCl}$ was not detected. None of the patients developed $\mathrm{OBI}$ or $\mathrm{OCl}$ activation in five-years follow-up. Renal transplantation was performed in one of the $\mathrm{OBI}$ patients and lifelong prophylaxis was planned with oral antiviral medication.

Conclusion: Presence of $\mathrm{OCl}$ is lower than $\mathrm{OBI}$ in hemodialysis patients.

Keywords: Occult Hepatitis B, occult hepatitis C, hemodialysis
\end{abstract}

ÖZ

Amaç: Bu çalışmanın amacı hemodiyaliz hastalarında okült hepatit $B$ enfeksiyonu (OBE) ve okült hepatit $C$ enfeksiyonu (OCE) varlığını araştırmak ve izlemde aktivasyon olup olmadığını tespit etmektir.

Gereç ve Yöntemler: Çalışmaya, normal alanin aminotransferaz (ALT) düzeyine sahip 100 HD hastasının demografik verileri, böbrek yetmezliği nedenleri, hemodiyalize erişim, hemodiyaliz süresi, ALT düzeyi ve hepatit göstergeleri kaydedilmiştir. Serum anti-hepatit $B$ çekirdek antikoru (anti-HBc) immünoglobulin G (lgG), ELISA (Architecht, Abbott) ile test edilmiştir. Serum HBV-DNA, HCVRNA [periferik kan mononükleer hücrelerinde (PKMNH)] "gerçek zamanlı" polimeraz zincir reaksiyonu yöntemi ile araştırılmıştır. Bulgular: Hastaların \%27'sinde anti-HBc lgG pozitifliği saptanmıştır, ancak izole anti-HBc lgG pozitifliği bulunmamaktadır. Hastaların \%4'ünde HBV-DNA pozitifliği ve OBE tespit edilmiştir. Hiçbir hastada serum ve PBMNH'de HCV-RNA pozitifliği bulunmamıştır, bu nedenle OCE saptanmamıştır. Beş yllık takip süresince hiçbir hastada OBE veya OCE aktivasyonu gelişmemiştir. OBE hastalarından birinde böbrek nakli yapılmıs ve oral antiviral ile yaşam boyu profilaksi planlanmıştır.

Sonuç: Hemodiyaliz hastalarında OCE varlığı OBE'den düşüktür. Anahtar Kelimeler: Okült hepatit B, okült hepatit $\mathrm{C}$, hemodiyaliz

Zanapalıoğlu Gazel 0̈, Şener A. Which is More Important and Insidious in Dialysis Patients? Occult Hepatitis B or 0ccult Hepatitis C?. Viral Hepat J. 2020;26:39-42. 


\section{Introduction}

In patients with chronic renal failure (CRF), infections are important causes of morbidity and mortality. These patients are particularly at risk of parenterally transmitted viral hepatitis (1). Hepatitis $\mathrm{B}$ and $\mathrm{C}$ viruses (HBV and $\mathrm{HCV}$ ) are primarily transmitted parenterally in dialysis patients. Chronic hepatitis B (CHB) Chronic hepatitis $\mathrm{C}$ and $(\mathrm{CHC})$ are more common infectious agents in patients with CRF compared to the normal population. These infections are also causes morbidity and mortality in patients with CRF and in patients undergoing renal transplantation $(2,3)$. According to the Turkish Nephrology Association; hepatitis B surface antigen ( $\mathrm{HBsAg}$ ) positivity was $2.65 \%$ and anti-HCV positivity was 3.94\% in hemodialysis patients in Turkey at 2017 (3).

HBV infection recovery defined as HbsAg dissaperance with HBV-DNA negativity in case of anti-Hbs positivity. The evaluation of serological markers for determining the infection is important but may be insufficient. Sensitive polymerase chain reaction (PCR) techniques have shown a low level of HBV-DNA in some patients who have spontaneously and serologically lost their HBsAg in serum and/or liver. Therefore, this condition, which defines chronic HBV infection (by PCR) with undetectable HBsAg levels, is called occult HBV infection (OBI) (4). OBI is divided into two groups according to anti-HBc and anti-HBs positivity.

The actual cause of approximately $10 \%$ of liver enzyme abnormalities is unknown. In the last decade, $\mathrm{OCl}$ has been defined with studies have been conducted to identify patients with chronic liver disease whose etiology has not been clarified. Firstly HCV-RNA was detected in liver cells when anti HCV and HCV-RNA were negative in serum. Thereafter HCV-RNA was found in liver and in peripheral blood mononuclear cells (PBMNC) with undiagnosed high liver function tests. Viral RNA can be detected in PBMNC over $70 \%$ of patients with $\mathrm{OCl}(5,6)$.

$\mathrm{OCl}$, firstly defined by Castillo et al. (6) HCV-RNA is detected in liver cells, while serum anti-HCV and HCV-RNA was negative. In the following years, Fabrizi and Martin $(7,8)$ defined $\mathrm{OCl}$, in patients with elevated liver enzyme; serum anti HCV and HCVRNA were negative, whereas HCV-RNA was detected in liver cells and PBMNC $(7,8)$. Recent studies report two different types of $\mathrm{OCl}$; seronegative and positive. In both types of OCl, HCV-RNA is positive in liver cells of patients, and viral RNA can be detected in PBMNC with serum ultracentrifugation $(9,10)$.

The aim of this study was to investigate the presence of $\mathrm{OBI}$ and $\mathrm{OCl}$ in hemodialysis patients in Çanakkale, and follow up the reactivation of $\mathrm{OBI}$ and $\mathrm{OCl}$.

\section{Materials and Methods}

This study was approved by the Çanakkale Onsekiz Mart University Ethics Commitee (approval number: 2014/03, date: 05.02.2014). We included 100 patients over 18 years of age and written informed consent was obtained from the patients. Patients were selected who had normal alanine aminotransferase (ALT) levels and shows seronegativity for HbsAg and anti-HCV antibody tests. The demographic data, ALT levels, hemodialysis periods, hepatitis B vaccination history, HBsAg, anti-Hbs and anti-HCV indicators were recorded.
Peripheral venous blood samples were collected from $5 \mathrm{~mL}$ each of 3 separated biochemistry tubes for anti-HBc Immunoglobulin $\mathrm{G}$ (lgG), HBV-DNA, HCV-RNA, and an amount of $9 \mathrm{~mL}$ blood in EDTA tube for PBMNC separation.

Anti-HBc lgG test was carried out with the Architect anti-HBC II Reagent kit. Blood samples for HBV-DNA and HCV-RNA isolation were centrifuged at $1500 \mathrm{rpm}$ for 15 minutes. The obtained sera were stored at $-20{ }^{\circ} \mathrm{C}$ until isolation of DNA and RNA.

Whole blood $(9 \mathrm{~mL})$ was taken into the EDTA tube for further differentiation of PBMNC. Histopaque (R)-1077 (9 mL) was added to $50 \mathrm{~mL}$ falcon tube. Gently drop whole blood with sterile pasteur pipette from the edge of the falcon tube onto the Histopaque $\circledR$-1077. According to the manufacturer's recommendations, it was centrifuged at $400 \mathrm{G}$ cycle for 30 minutes. After centrifugation, the cells in the cloud appearing in the middle of the tube were identified as PBMNC, and these cells were taken to the microvida lid cryo tubes by taking $3 \mathrm{~mL}$ with the help of micropipette. RNA was stored at $-20{ }^{\circ} \mathrm{C}$ until isolation.

Prepared serum and PBMNCs after DNA/RNA isolation using HBV-DNA and HCV-RNA isolation kit (Magnesia®-2448 nucleic acid isolation and PCR setup robot) in Anatolia Diagnostic and Biotechnology R\&D laboratory Montaina $₫ 4896$ real time (RT)-PCR Bosphore ${ }^{\circ} \mathrm{HBV} / \mathrm{HCV}$ quantification (analytical sensitivity is $25 \mathrm{IU} /$ $\mathrm{mL}$ and its linear range is $1 \times 10$ duy- $1 \times 10 \mathrm{v} \mathrm{UU} / \mathrm{mL}$ ) was performed using Kit V1.The Bosphore® HBV Quantification Kit v1 (analytical sensitivity of $10 \mathrm{IU} / \mathrm{mL}$ and a linear range of $1 \times 10$ analytic- $1 \times 10$ Kit $\mathrm{IU} / \mathrm{mL})$.

OBI was defined as HBV-DNA positivity in patients with HBsAg negative and with normal ALT levels.

$\mathrm{OCl}$ was defined as HCV-RNA positivity in patients with antiHCV negative in patients with normal ALT levels.

\section{Statistical Analysis}

SPSS 20.0 package program used for data collection, recording and analysis.

\section{Results}

The study included 100 patients with normal ALT levels and $\mathrm{HBsAg}$ negative, anti-HCV negative in one dialysis center in Çanakkale province. Demographic data of the patients included in the study are given in Table 1. Fiftyeight (58\%) of the patients were male and 42 (42\%) were female. The mean age was $63.5 \pm 12.5$ years. Eighty-five (85\%) patients underwent dialysis through arteriovenous fistula. Other patients underwent dialysis with a

\begin{tabular}{|c|c|}
\hline Age (year), \pm SD & $63.5 \pm 12.5$ \\
\hline Gender (female/male) & $42 / 58$ \\
\hline Comorbid diases (other than CRF), n (\%) & $88(88 \%)$ \\
\hline \multicolumn{2}{|l|}{ Hemodialysis way } \\
\hline Catheter, n (\%) & $15(15 \%)$ \\
\hline A/V fistula, n (\%) & $85(85 \%)$ \\
\hline Total hemodialysis time (month), \pm SD & $67.6 \pm 51.3$ \\
\hline $\mathrm{ALT}, \pm \mathrm{SD}$ & $10.5 \pm 7.2$ \\
\hline
\end{tabular}




\begin{tabular}{|l|l|l|l|l|l|l|}
\hline Table 2. Occult Hepatitis B diagnosed patients' characteristics \\
\hline Patient Number & Age & Gender & HD way & Total HD time (month) & HBV DNA level (IU/mL) & Anti Hbs titer (mIU/mL) \\
\hline$(42)$ & 33 & M & AVF & 59 & 61.4 & 1000 \\
\hline$(58)$ & 61 & M & AVF & 112 & 56.9 & 270 \\
\hline$(98)$ & 67 & F & AVF & 93 & 60 & 220 \\
\hline$(100)$ & 67 & M & AVF & 27 & 48.6 & 21 \\
\hline HD: Hemodialysis, AVF: Arteriovenous fistula, M: Male, F: Female & \\
\hline
\end{tabular}

permanent hemodialysis catheter. The mean duration of dialysis was 67.6 months. $95 \%$ of the patients had dialysis 3 days a week and $5 \%$ had 2 days dialysis. When the serological tests of the patients are examined; 27 patients $(27 \%)$ were showed anti-HBc $\lg \mathrm{G}$ and anti-HBs positivity together. None of the patients had antiHBc IgG positivity alone. HBV-DNA was positive in $4(4 / 100,4 \%)$ of all patients. OBI diagnosed patients' characteristics were shown at Table 2. When the hepatitis B vaccination history were examined, it was seen that $55 \%$ had at least three doses.

There was not any clinical and laboratory activation of hepatitis $B$ in five-years follow-up of these four patients. Serum and PBCMN were investigated by PCR for OCl and HCV-RNA was not detected in any of the patients. The general characteristics of 27 patients with anti-HBc IgG positive are in Table 2. The mean age of the patients was $57 \pm 16.2$ years. The mean duration of hemodialysis was $72.7 \pm 37.5$ months. ALT levels were within normal limits and the mean was $9.7 \pm 2.3 \mathrm{IU} / \mathrm{mL}$.

\section{Discussion}

Although HBsAg positivity was decreased in hemodialysis patients, HBV viremia OBI was shown by PCR tests. The prevalence of $\mathrm{OBI}$ varies from $1 \%$ to $87 \%$ in different regions of the world (11).

The incidence of $\mathrm{OBI}$ is different in every country, for example it has been reported between $0 \%-36.4 \%$ in blood donors in our country (12). According to other studies, OBI was reported actullay between $3.4 \%$ and $19 \%$ in hemodialysis patients (13). In this study, we investigated the presence of $\mathrm{OBI}$ and $\mathrm{OCI}$ with RT-PCR in hemodialysis patients. In our study, the incidence of OBI was found $4 \%$. But $\mathrm{OCl}$ was not obtained in our study group. In Egypt, Helaly et al. (14) found anti-HBc lgG positivity in all patients who had detected OBI. Therefore, in the presence of anti-HBc IgG positivity, patients should be investigated for possible OBI by molecular methods (14). But in our study none of the OBI patients did not showed this antibody positivity for core antigen. In our opinion, the main cause of this stiutaion is; core antigen production was irregular in hepatocytes. If the replication continues regularly, you can detect antibody response, but if not antibody shows negativity. In hemodialysis patients this irregular sythesis might be in maximum level because of the CRF.

In the study conducted by Fontenele et al. (15) in Brazil, 79\% of 301 patients with CRF who had hemodialysis showed anti-HBs positivity and isolated anti-HBs positivity was detected in only $35 \%$ of the patients. They found OBI in three patients with antiHBs positivity alone. Anti-HBs positivity was found in $95 \%$ of our patients and $68 \%$ of patients have been showed anti-HBs positivity alone. All of $\mathrm{OBI}$ patients showed anti-HBs positivity alone.

Although the exact cause is unknown, the presence of anti-
HBs in hemodialysis patients with $\mathrm{OBI}$ suggests that inadequate neutralization of virus and routine serological profiles alone are not always sufficient to define the status of HBV infection.

There are also important studies on the clinical consequences of $\mathrm{OBI}$ in organ transplant patients. Each hemodialysis patient is a candidate for kidney transplantation. Before solid organ transplantation, recipients should be screened for serological tests (HBsAg, anti-HBs, anti-HBc lgM, lgG or total, anti-HCV) for possible hepatitis. In hemodialysis patients receiving immunosuppressive therapy before and after transplantation, viral activation of HCV and HBV might have seen and also cause fulminant hepatitis. Screening with appropriate methods before solid organ transplantation will increase transplant success (16). Therefore, it is suggested that these patients should be evaluated in terms of HBV-DNA search by molecular methods.

One of the $\mathrm{OBI}$ patient has been undergone renal transplantation. Oral antiviral prophylaxis has been began and hepatitis B viral activation hasn't seen as other OBI patients in five-year follow-up.

\section{Study Limitations}

Our study population was not enough to make a general recommendation for management of $\mathrm{OBI}$ in all dialysis patients.

\section{Conclusion}

In our study, we found the incidance of OBI $4 \%$ in seronegative hemodialysis patients, but $\mathrm{OCl}$ was not obtained. When the infectious properties of these patients are also taken into consideration, it is inevitable that HBV negative patients will be infected by dialysis. It is an important risk factor that may adversely affect morbidity and mortality in these patients whose quality of life has decreased significantly due to CRF. Since our key diagnostic method for detection of OBI is HBV-DNA, it is essential to standardize the technique and used method. During the followup in dialysis units, once a year, viral DNA analysis with PCR-based method can be helpful in preventing the problems that may occur in the expected for organ transplantation.

\section{Acknowledgements}

This study was financially supported by the Turkish Viral Hepatitis Association. This study is presented as an oral presentation in ICC 2017 in Taipei-TAIWAN.

\section{Ethics}

Ethics Committee Approval: This study was approved by the Çanakkale Onsekiz Mart University Ethics Commitee (approval number: 2014/03, date: 05.02.2014).

Informed Consent: Written informed consent was obtained from the patients.

Peer-review: Externally and internally peer-reviewed. 


\section{Authorship Contributions}

Surgical and Medical Practices: Ö.Z.G., Concept: Ö.Z.G., A.S., Design: Ö.Z.G., A.S., Data Collection or Processing: Ö.Z.G., A.S., Analysis or Interpretation: Ö.Z.G., A.S., Literature Search: Ö.Z.G., A.S., Writing: Ö.Z.G., A.S.

Conflict of Interest: The authors declare no conflict of interest.

Financial Disclosure: The authors declare that this study has not received any financial support.

\section{References}

1. Aygen B. Özel hasta gruplarında infeksiyon kontrolü: hemodiyaliz hastalarında infeksiyon kontrolü. Hastane Infeksiyonları Dergisi. 2001;5:247-285.

2. Çiftçibaşı I, Örmeci A, Karaca Ç. Viral Hepatitler ve Kronik Böbrek Yetersizliği. Viral Hepatit 2013 (1.baskı). İstanbul. Viral Hepatitle Savaşım Derneği Tabak, F, Tosun S. Bölüm 35.

3. Süleymanlar G, Altıparmak MR, Seyhani N, Trabulus S. Türkiye'de nefroloji, diyaliz ve transplantasyon registry 2017. Ankara. Türk Nefroloji Derneği Yayını.

4. Ergünay K. Gizli (okült) hepatit b enfeksiyonu. Mikrobiyoloji Bülteni. 2005.39: 241-249.

5. Barril G, Casillo I, Arenas MD, Espinosa M, Garcia- Valdesas. Occult hepatitis c virus infection among hemodialysis patients. J Am Soc Nephrol. 2008;19:2288-2292.

6. Castillo I, Pardo M, Bartolome J, Ortiz-Movilla N, RodriguezInıgo E, de Lucas S, Salas C, Jiménez-Heffernan JA, Pérez-Mota A, Graus J, López-Alcorocho JM, Carreño V. Occult hepatitis c virus infection in patients in whom the etiology of persistently abnormal results of liver-function tests is unknown. $\mathrm{J}$ Infect Dis. 2004; 189:7-14.

7. Ocana S, Casas ML, Bugihas I, Lledo JL. Diagnostic strategy for occult hepatitis b virus infection. World J Gastroenterol. 2011;17:1553-1557.

8. Fabrizi F, Martin P. Occult hepatitis c virus infection in hemodialysis. J Am Soc Nephrol. 2008;19:2248-2250.

9. Carreno V. Occult hepatitis c virus infection: a new form of hepatitis c. World J Gastroenterol. 2006;12: 6922-6925.

10. Carreno V. Seronegative occult hepatitis $C$ virus infection: clinical implications. Journal of Clinical Virology.2014;61:315-320.

11. Makvand M. Update on occult hepatitis B virus infection. World J Gastroenterol 2016;22:8720-8734.

12. Afyon $M, A v c ı$ IY, Ülçay A, Diktaş H. Occult hepatit B enfeksiyonu. J Clin Anal Med. 2013;4:435-439.

13. Kazmierczak J, Pawelczyk A, Cortes KC, Radkowski M. Seronegative hepatitis $C$ virus infection. Arch Immunol Ther Exp. 2014;62:145-151.

14. Helaly GF, Ghazzawi EF, Shawky SM, Farag FM. Occult hepatitis $b$ virus infection in among chronic hemodialysis patients in Alexandria, Egypt. J Infect Publıc Health. 2015.

15. Fontenele AMM, Gainer JB, Silva E DV, Cruz Santos MD, Salgado Filho N Ferreira AS. Occult hepatitis B among patients with chronic renal failure on hemodialysis from a capital city in northeast Brazil. Hemodial Int. 2015;19:353-359.

16. Jamali $R$. The importance of occult hepatitis $B$ infection screening in pre-transplant evaluation. Thrita J Med Sci. 2014;3:e16044. 